\title{
Corporate governance and Real Activities Manipulation (Real Earnings Management)
}

\author{
GholamhassanTaghizad (gt_a23@yahoo.com) \\ Accounting and Management Department, Kashan Branch of IAU \\ Dr. HosienPanahian (panahian@yahoo.com) \\ Accounting and Management Department, Kashan Branch of IAU
}

\begin{abstract}
This paper is performed based on the relation between corporate governance on Iranian corporations' performance $2006-2012$ financial years. The aim of this study is to determine the relationship between the elements of firm sovereignty and the management of real profit in the realm of the study. The methodology of the study is based on the drawing a conclusion and the gathering of descriptive data and also based on practical application aim. The descriptive method is from correlated type and multi variable regressions are used to analyze the data and to examine assumption. Considering the first basic assumption (among firm sovereignty (concentration of ownership) and second assumption (between firm sovereignty (independence of the board of directors) and handling real activities there is a relation. The obtained conclusions show that: based on the first assumption there is a negative and meaningful relation between independency of board of directors and management of real profit based on unusual expenses of production. However no meaningful relationship was observed between concentration of property and real earning management. Based on the second assumption: there is a negative and meaningful relationship between the independency of the board of directors and the real management of real profit based on arbitrary expenses, however when the previous models is based on management of real profit model and arbitrary expenses and is considered, no meaningful relationship was observed between concentration of the property and possession and real earning management.
\end{abstract}

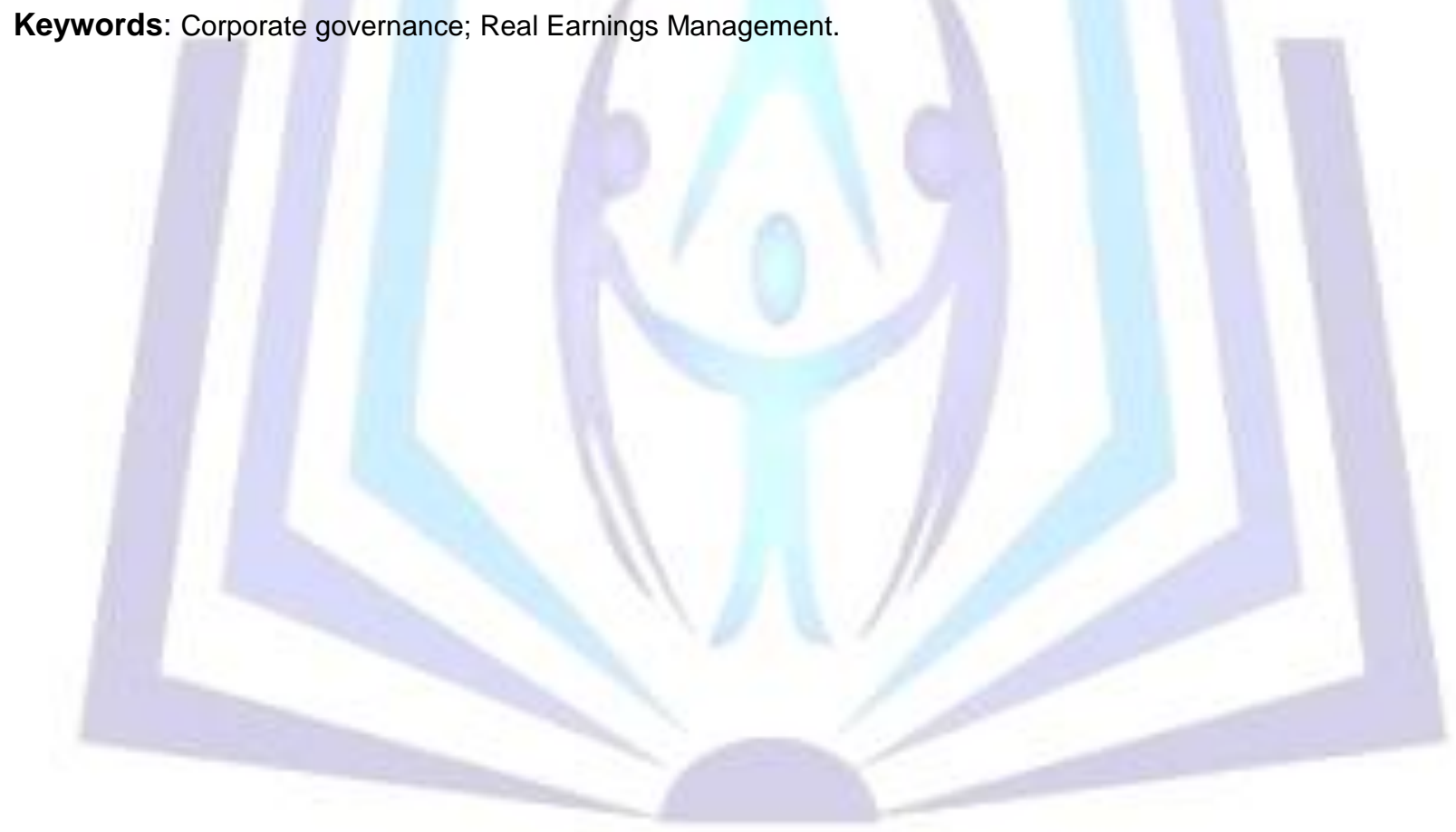

\section{Council for Innovative Research}

Peer Review Research Publishing System

\section{Journal: Journal of Social Sciences Research}

Vol. 5, No. 2

Jssreditor.cir@gmail.com

www.jssronline.com 


\section{2) Introduction:}

When corporate governance composition involved in weak principles, there will be an increasing contradiction between great and the small investors or corporate governance may be taken into as a strong tool to decrease agencies' expenses. So according to the agency definition, investors and shareholders' biggest problem is their endeavorto gain approaches and means that can assure the sufficiency of their financial information.

The present paper is insearch of solving problems of real earnings management by managers through strengthening corporate governance elements. Research results feel lead into better and effective control on real earnings management and information quality promotion and consequently better decision-making provided that there would be a relation here and gaining applied results. Since real earnings management as a main form of earnings management is not paid much attention by both foreign and Iranian researchers, so there are important aspects of this matter relation with some other variables that left without answers. Here the main question is that how much corporate governance elements can influence manipulation of firms' real activities (real earnings management)?

The present study is in search of and is about the trial of this matter that applying which one of corporate governance elements can limit real activities manipulation and how much can this main issue influence reduction of agencies expenses? This study tries to convey the relation of mentioned variables and to measure the relation extent. Like the other researches on real earnings management, this paper begins with recognizing commercial activities unusual levels using expecting models (the models that provide the expected figure for a variable or phenomenon) and considers deviation rate from expected rate as an agent for management manipulation two criteria were used in order to determine manipulation rate of real activities (earnings real management) including manufacturing unusual expenses and abnormal discretionary expenses.

\section{2) Literature review}

Jensen, M. C. (1986) concluded in his research when institutional ownership percentage is adequately the great, institutional owners' monitoring prevents managers' weak performance.

Morck, R., Shleifer, A., \&Vishny, R. W. (1988).Hermalin, B. E., \&Weisbach, M. S. (1991). Demsetz, H., \& Lehn, K. (1985). Examined effect of ownership structure on firm performance. Their research results show that there's a positive and important relation between ownership structure and firm performance.

Fosberg, R. H. (1989). Found that there is no significant relation between performance variables and non-bound members' presence; such variables selling, staffs' numbers, and shareholders' salary efficiency.

Rosenstein, S., \& Wyatt, J. G. (1990). Evaluated the effect of outside managers' ratio in the board of directors and shareholders' wealth this research indicated that there is a direct relation between increasing board of directors outside managers' ratio and fears value. They attribute this value increase to monitoring on the firm management by outside managers of board of directors and consequently to firm performance improvement.

Jensen, M. C. (1993).Declared that since board ownership percentage increase is in line with managers' and shareholders' profit, so it will lead to firm performance increase via decreasing agency's expenses.

Ramsay, I. M., \& Blair, M. (1993). Showed that great deal of ownership concentration provides enough incentives for major shareholders to monitor managers.

Dempsey, S. J., Hunt, H. G., \& Schroeder, N. W. (1993). Detected that different levels of ownership concentration are related with different levels of opportunistic earnings' management. However some researchers show that concentrated ownership can harm firm value, more specifically when major shareholders not only possess firm concentrated ownership but they also participate in managerial teams.

Yermack (1996), studying a sample of 452firms during 1991-2003, indicates that when CEO and board chairman are two different individuals, the firm is of higher value.

Beasley, M. S. (1996) found out in his research that the more non-bound members of the board increase, the less possibility of deception will be found in fiscal notes.

Agrawal, A., \&Knoeber, C. R. (1996).Concluded that institutional shareholders concentration can increase management monitoring, so that it can improve firm performance. Press enter

Dechow, P. M., Sloan, R. G., \& Sweeney, A. P. (1996) concluded in their study that in companies having strayed from accounting accepted principles and exaggerated their earnings reports it's possible that interior managers would be dominant to the board of directors and perhaps managing directors and board chairman maybe the same person, and definitely there would not rather be an auditing committee and ultra-organizational major shareholders.

Burgstahler, D., \&Dichev, I. (1997) concluded that there is a higher possibility for doing earnings management in companies having several various shareholders comparing companies having major shareholders.

Black, B. S. (1998) believed that firms having several various owners and without major shareholders have more incentives for earnings management. 
Pope, P., Peasnell, K., \& Young, S. (1998) examined the relation between management rewards and earnings management. Research results show that there is a negative significant relation between earnings multiplying accruals and ratio of outside board members.

Bushee, B. J. (1998) believed that there's a higher possibility to perform earnings management in companies within which ownership is mainly belonging to institutional investors,(comparing other companies) since institutional investors' behaviors are temporary and changeable and they aim at short terms keeping sharers.

Healy, P. M., \&Wahlen, J. M. (1999).Bergstresser, D., \&Philippon, T. (2006) pointed to some issues such as accelerating product sales and, correcting timing program of products' delivery, delay in expenditure on development and research and saving expenses, maintenance and repairing as a part of earnings manipulation process.

Himmelberg, C. P., Hubbard, R. G., \&Palia, D. (1999) didn't notice any relation between non-bound members ratio and performance, while others, concluded that there is a positive relation between non-bound manager's ratio and performance.

Degeorge, F., Patel, J., \&Zeckhauser, R. (1999)found out that earnings can be manipulated through manipulation of accruals management, changing economic events (real management) or a combination of both; they also concluded that non-bound managers and major institutional investors have a close relation with Earnings management.

Rajgopal (1999), Yermak (1996), and Rechner and Dalton (1991) found out that the firms having a non-bound chairman in their board of directors, perform better than the ones under CEO's influence. If CEO's influence decreases monitoring the management, it will probably decrease the information content of earnings, too. In other words, there is a reverse relation between $\mathrm{CEO}^{\prime}$ (chief executive officer')s influence and the information content of earnings.

Dechow, P. M., \& Skinner, D. J. (2000). Found out that firms managing directors (CEO) reduce expense for firm's development and fulfillment thereabout the end of their management period in order to increase accounting interest and in result to increase their end of service rewards.

Bennedsen and Wolfenzon (2000) found out that there is a negative significant relation between ownership concentration and earnings management.

Peasnell (2000) indicated that there is a reverse relation between the number of non-bound directors and the possibility of unusual accruals management in order to avoid loss or earnings loss reporting.

Lehmann and Jorjen (2000), using 361 German firms during 1991-1996, indicated that 1) the presence of many shareholders does not necessarily increase profitability, and 2) a high degree of ownership concentration seems less than optimal for many German firms. Their results, also, imply implicitly that ownership concentration has a negative significant impact on profitability.

Black (2001) found out from a research study conducted in Russia that there is a relation between corporate governance and firm performance. In a similar study in the USA, Gumperz, Easti, and Metrik (2003) came to the same conclusion.

Marrakchi (2001) studied corporate ownership and its effect on earnings management and the quality of information disseminated to the public. He states that non-bound members of the board and audit committee restrain largely earnings management activities.

Chtourous, et al. (2001) found that there is a negative relation between the amount of board's independence and the level of earnings management.

Bedard, Chtourou, and Courteau (2001) found that there is a positive relation between discretionary accruals and having CEO as the board chairman.

Rajgopal, et al. (2002), Balsam, et al. (2002) indicated that increasing institutional ownership reduces directors' incentives to manipulate earnings, and thus it increases the information content of earnings. However, Fun and Wanng (2002), studying this relation in East Asian firms, found other results and indicated that this relation is reversed in East Asia; the more the level of institutional ownership, the less the information content of earnings.

Kinney (2002) concluded that ownership structure affects earnings management, and it is a strong incentive for that. The findings are similar to the findings of Darrough, et al. (1998) on Japanese firms.

Lawler, et al (2002) presented data and information which shows that board members' independence is an important factor in enhancing and strengthening the monitoring role of board members.

Chung (2002) and Klein (2002), studying the relation between institutional investors and accruals management, found that institutional investors prevent from management engagement in managing accruals for facilitating the earnings in order to achieve the desired level of profitability.

Anderson, et al. (2003) concluded that board independence is positively related to the information content of earnings.

Rosenberg (2003) concluded from his researches that firms implementing corporate governance appropriately, enjoy stock returns, firm value, and cash flow ratio, compared to the firms which have an inappropriate corporate governance. 
Koh (2003) studied the relation between institutional ownership and earnings management in Australian firms. The results showed that institutional ownership reduction leads to increased earnings management, and also, increasing institutional ownership leads to the earnings management reduction.

Xie (2003). The results showed that there is a reverse relation between independent non-bound directors and discretionary accruals.

Gul, and Leung (2004) found out from their research that there is a positive significant relation between CEO's influence and earnings management.

Jae-Seung, Jun-koo, and Kyung-Suh (2004) came to the following conclusions: better directors make better corporate governance, and they pay attention to their stakeholders, and there is a positive relation between firm value and corporate governance.

Peasnell, K. V., Pope, P. F., \& Young, S. (2005) showed that a monitoring that is attributable to corporate governance reduces managers' contents for earnings management so it can improve useful notifying ability of accounting earnings.

Peasnell, et al. (2005) studied earnings management in England. Considering board of directors, their study focuses on the role of non-bound directors and audit committee. The results showed that there is a reverse relation between the number of non-bound directors and the probability of unsual accruals management in order to prevent loss or earnings reduction reporting.

Ramsey and Mather (2005) found a non-linear relation between the percentage of board ownership and earnings quality, and a positive relation between the proportion of independent directors and earnings quality. They also found that there is no relation between the number of board members and the level of earnings quality.

Gunny (2005) concluded from his research study that firms that had limitations in increasing earnings through accruals, had decreased public, administrative, and sale expenses.

Almazan, et al. (2005). Their findings indicate that institutional shareholders who have no commercial relation with the firm, have an essential role in the regulation and proper management of managerial activities.

Saleh, Iskandar, and Rahmat (2005) indicated in their research entitled " Earnings Management and Board Characteristics in Malaysia" that there is a reverse relation between discretionary accruals, as an index of earnings management, and directors ownership, but it is a direct relation while considering the role of CEO as the board chairman. The results also state that multiple management factor is effective in the discovery of earnings management activities in order to hide the loss.

Roychowdhury (2006) studied the impact of board's reward on the earnings management in Canadian firms. The results indicate that on the contrary to outside board of directors, earnings management is first decreased by non-bound board of directors, and then decreased more by active institutional shareholders' board.

AbdolRahman and FiroozanaHanim (2006). The results show that earnings management is in direct relation with the number of board members.

Velury and Jenkins (2006) studied the relation between stock institutional ownership and earnings quality during 1992 1999. The results indicate that there is a positive significant relation between stock institutional ownership and earnings quality. Also, the findings showed that there is a negative significant relation between ownership concentration and earnings quality. Niu (2006) achieved the same results in Canadian firms.

Frank Yu (2006) studied the relation between corporate governance and earnings management. He categorized corporate governance variables into two internal and external categories. Internal variables include ownership concentration and board structure, and external variables include institutional ownership. The results indicate that firms with stronger internal variables are more likely to manage earnings, compared to firms with stronger external variables.

Cheng and Courtenay (2006) indicated that firms with a higher proportion of independent board members, or the ones in which most board members are independent ones, have higher levels of voluntary disclosure.

Yu (2006) suggested in his researches that higher institutional shareholders lead to lower earnings management.

Mueller and Spitz (2006). The results show that the performance of firms with a managerial ownership percentage of above $40 \%$ is being improved.

Bhattacharya, and Graham (2007) studied the relation between stock institutional ownership and firm performance in Finland. The results imply a significant two-way feedback between firm performance and stock institutional ownership.

Imam and Malik (2007), their research findings show that corporation ownership has a positive significant impact on corporation performance, and the focus of managerial ownership has a negative significant impact on dividend policy.

Osma, et al. (2007) studied the role of board's reward and a board monitoring committee in limiting earnings management for Spanish firms in 1999-2001. The results indicate that earnings manipulation is significantly determined through the board's reward. Therefore, this limitation is conducted by institutional members of the board of directors, instead of the independent ones. 
Kapopoulos, et al. (2007) studied "Corporate Ownership Structure and Firm Performance". Using the information of 175 Greek firms, they concluded that a more concentrated ownership structure has a positive relation with higher profitability; and also, the lower the ownership dispersion, the higher the profitability.

Firth, et al. (2007), using a sample of 5189 observations in 1998-2003, studied the impact of corporate ownership structure on the information content of Chinese firms earnings. They concluded that ownership concentration, the presence of foreign stockholders, individual ownership, the kind of major stockholders' ownership, monitoring committee, and board composition affects earnings response coefficient (CRO).

Wallas Davidson and Bayo V. Yong (2007) evaluated managerial incentives in earnings management. Directors close to retirement are more likely to apply earnings maximizing strategies. Researchers concluded that the firms in which the senior directors are close to retirement, have higher discretionary accruals in the year before the change. Also, firms that have greater reward program, have higher discretionary accruals.

Hashim and Devi (2007) studied the relation between corporate governance, ownership structure, and earnings quality of Malaysian firms during 1999-2005. The results indicate that there is a positive significant relation between stock institutional ownership and earnings quality; and, increasing institutional shareholders increases the quality of earnings, significantly. They also indicate that there is no relation between non-bound directors of the board and earnings quality.

Setia- Atemja, et al. (2008) studied the impact of board size and its independence on earnings management. Their sample consists of family and non-family listed firms in Australian Stock Market during 2000-2004. Data- panel results indicate that independent board of directors are negatively related to earnings management.

Chang (2008), using a sample of 989 American and 88 non-American firms, concluded that there is a positive significant relation between board composition and information content of earnings, as well as a negative significant relation between the duality of CEO's responsibility and the information content of earnings.

Siregar (2008), in a similar research showed that directors of Jakarta Stock Exchange tend to use effective earnings management, more. As well, in the family-owned firms that don't belong to a business group, the directors are more likely to apply effective earnings management. In contrast, firm size, corporate governance, and institutional shareholders have no impact on directors' tendency to choose the type of earnings management.

Jiang, et al. (2008) conducted a research study on the relation between corporate governance and earnings management. The results show that there is a significant relation between increasing corporate governance and decreasing discretionary accruals and increasing earnings quality; and in firms with poor corporate governance, earnings management is more probable.

Yu (2008), Gunny (2010), Cohen and Zarowin (2010) concluded from their research studies that the firms more willing to manage earnings, manipulate actual activities more than other firms. Their findings show that the manipulation of actual activities might destroy firm value, in the long term.

C. War Makerishnan and Yu (2008), SitaAmaja (2008), Ramisi and medr (2005), and Klein (2002) concluded that when the number of non-bound directors is increased in the board of directors, discretionary accruals are decreased, and nonbound directors enhance earnings quality.

Chang and Sun (2008) found that the duality of CEO's responsibility might endanger the effectiveness of board of directors' monitoring on financial reporting. Finally, they concluded that there is a positive significant relation between the duality of CEO' responsibility and earnings quality.

Zouari, et al. (2009) studied the relation between stock institutional ownership and earnings management in American firms. Using neural networks test, the results show that having institutional owners in capital structure leads to the reduction of the amount of earnings management.

Ali Shah, et al. (2009) studied the relation between board's reward and earnings management in 120 Pakistani firms. Using general effects model, the results indicate that there is a negative relation between institutional ownership and earnings management.

Epps et al. (2009) categorized American firms into three groups: firms with very positive accruals, firms with very negative accruals, and firms with small (close to zero) accruals. Their results showed that very negative accruals happens in the firms that select their board of directors annually in small number, and have independent trading and rewarding committees. Also, there are very positive accruals in the firms that have a relatively independent board of directors and a relatively small size.

Chung, Elder, and Kim (2009) studied "Corporate Governance and Liquidity" and concluded that good governance, financial and operational transparency leads to the increase in Stock Market liquidity, and therefore reduces information asymmetry between local and foreign investors.

Ben Ali (2009) found that institutional American investors in France, reduce the agency compensation, and better and more beneficial disclosure demand, and thus they reduce information asymmetry.

Chang and Sun (2009), as part of their research, studied changes made in information content of earnings as a result of Sarbense-Oxely Act. The results indicate that there is a positive significant relation between the percentage of non-bound members of the board and information content of earnings pre and post SOX. Furthermore, they found that there was no 
significant relation between board chairman and CEO, pro the Act, while there is a positive significant relation, post the Act.

Chang and Sun (2010) investigate the effect of corporate ownership structure disclosure on market's precision of information content and earnings management. They concluded that a stronger corporate ownership structure makes the market more reactive to earnings changes.

Hung and Peng (2010) concluded from a research entitled "the impact of Corporate Governance on Earnings Quality", that in the presence of information asymmetry between directors and investors, corporate governance might have a major impact on earnings quality.

Kouki, et al. (2011) studied the impact of corporate governance on earnings management, and concluded that having independent audit committees and not having the duality of CEO's responsibility, avoids management.

Chang and Zhang (2011) studied "Corporate Governance and Institutional Ownership". Their study indicates that the proportion of corporate stock held by institutional investors increases the quality of governance structure.

Nelson (2011) studied the impact of corporate governance mechanisms on earnings management and concluded that a bigger and more active board of directors can help preventing from earnings management; and the duality of CEO's responsibility increases earnings management.

Midri (2003), studying ownership structure and its relation with active firms in Stock Exchange Market, found that Iranian Stock Market has a very concentrated ownership structure. In Iran, like China and Czech, a more concentrated ownership is associated with greater efficiency. In other words, ownership distribution has a negative impact on efficiency.

RahnamayRudposhti and Nabavi (2003) concluded from a research entitled "the Impact of Corporate Governance Mechanism on Earnings Management", that the more ownership concentration and independent board of directors, the less earnings management; and finally, there is a positive significant relation between the duality of CEO's responsibility and earnings management.

Khoshtinat, et al. (2004). Their research shows that directors tend to apply earnings management in firm's profit and loss periods, and also manage earnings in loss periods in order to increase their reward.

Mazloomi (2004), studying the impact of institutional investors, indicated that when the institutional investors ownership is classified as major shareholders, it decreases agency compensation. He observed a positive relation between the owned shares of institutional investors and corporate financial performance.

Noorvash and EbrahimiKordlar (2006). Their results showed that firms with a high percentage of corporate shareholders reported more information regarding upcoming earnings, compared to the firms with low percentage of corporate investors. As a result, more information asymmetry is observed in firms with low corporate ownership.

Yazdanian (2007) studied the impact of some measures of corporate ownership on earnings management reduction. The results indicate that the only measure affecting earnings management reduction is institutional investors. While, having non-bound members of the board, the separation of CEO and board chairman's roles, and also having an internal auditor has no impact on earnings management.

Mashayekhi (2007) studied the relation between corporate governance characteristics and earnings management. The findings imply that there is a significant relation between board size, the duality of CEO's responsibility, institutional investors' representatives in the board of directors and earnings management.

Qanbari (2008) studied the impact of non-bound members' proportion, information transparency, an internal auditor, and the presence of institutional investors as the measures of corporate governance on firm performance. The results show that the presence of institutional investors and internal auditors affect firm performance.

Mahavar Poor (2008) suggested that there is a significant relation between the ownership concentration and EPS standard; that is, the more ownership concentration, the more control on directors, which leads to the improvement of firm performance.

Yazdanian, Narges (2008) concluded from her MA thesis entitled "the Impact of Corporate Governance on Earnings Management" that while the institutional investors' ownership in firms, is more than $45 \%$, earnings management is reduced.

Namazi and Kermani (2009) studied the effect of ownership structure on firm performance. Studying 66 firms during $2003-$ 2007, they suggested that there is a significant relation between institutional ownership and firm performance, and a positive significant relation between corporate ownership and firm performance. Managerial ownership affects firm performance in a negative significant way.

Hadavi (2010) studied the relation between capital structure, ownership structure, and determining some influential characteristics on capital structure. The results imply a relation between capital structure and ownership structure.

Ahmad Poor, et al. (2010). The research studies the effect of non-bound directors and institutional investors as monitoring devices for corporate governance on earnings management. Their study indicates that in the cases of high incentives for earnings manipulation, non-bound directors and major institutional investors have a poor role in reducing the abnormality of unusual accruals. 
Moradzade, et al. (2010) studied the relation between earnings management and institutional ownership. In general, the results of this study imply a negative significant relation between the level of institutional ownership and its concentration, and earnings management.

Aghai and Chalaki (2010) studied the relation between corporate governance characteristics and earnings management. To measure earnings quality, the research uses abnormal accruals. The results imply that there is a negative significant relation between institutional ownership and board independence, and earnings management. But, there is no significant relation between other corporate governance characteristics and earnings management.

Ashrafi (2011) studied the relation between governance mechanisms and capital structure. The results of this study imply a significant relation between institutional ownership as the governance mechanism, and capital structure.

Nasrollahi and Arefmanesh (2011) studied the relation between ownership and earnings quality. Their results show that having institutional investors in firm ownership structure leads to presenting honest, more relevant, and timely information; and the concentration of institutional investors leads to the decreased earnings quality.

Setayesh, et al. (2011) studied the impact of corporate governance on facilitating earnings during 2004-2008. They concluded that board composition, institutional ownership, and managerial ownership affects earnings facilitation, while board independence does not affect earnings facilitation.

Zanjirdar, Amirhosseini, and Zmanai (2011) studied the relation between corporate governance mechanisms and earnings management in Iranian Capital Market. The results show that there is a reverse significant relation between the presence of an internal auditor, the percentage of major shareholders ownership and the proportion of non-bound members of board.

Izadinia and Rasaian (2011) studied the relation between some measures of corporate governance and economic financial standards of performance evaluation. They showed that there is a relation between corporate governance monitoring measures and all standards of performance evaluation.

Vakilifard and Bavandpoor (2011) studied the relation between corporate governance mechanisms and firm performance. The results imply that there is a positive significant relation between institutional investors and firm performance. They, also, found that there is a reverse significant relation between non-bound board members in board composition and firm performance.

Fazlzade, et al. (2011) conducted a research study aimed at determining the role of ownership structure on firm performance. They suggest that ownership concentration has no significant impact on firm performance, but institutional ownership has a significant impact on ownership concentration.

Nikbakht and RahmaniNia (2011) indicate that there is a positive significant relation between institutional ownership and firm performance.

Mashayekhi and Mohamamdabadi (2011), Ebrahimikordlar and Arabi (2011), Mashayekhi and Mohamadabadi (2011) studied the relation between corporate governance mechanisms and earnings quality. The results imply that as the board sessions and the number of non-bound directors in it increase, the outer-organizational ownership concentration, the quality (stability and prediction ability) of accounting earnings are increased.

Ismail ZadeMafari, et al. (2011) studied the impact of corporate governance on earnings quality. The results showed that there is a significant relation between institutional investors' ownership, the number of blocks for major investors, the percentage of non-bound directors, the duality of CEO's responsibility, the amount of firm's audit and earnings quality.

SohrabAsta (2012) studied the relation between capital structure and earnings management, he concluded that there is a negative significant relation between institutional ownership, managerial ownership and earnings management. But there is a positive significant relation between corporate ownership and earnings management.

Vali Poor and Khoram (2012) proved that there is a negative significant relation between the percentage of institutional investors' ownership, the percentage of managerial stock ownership, the percentage of non-bound members of board, the ratio of short-term to long-term debt, and agency compensation.

Karimi and Ashrafi (2012) studied the relation between corporate governance mechanisms and capital structure in Tehran Stock Exchange. The results indicate that there is a positive significant relation between institutional governance as an outside mechanism of corporate governance and capital structure.

\section{3) Research hypothesis:}

Major hypothesis: there is a relation between corporate governance and real activities manipulation (real earnings management).

\section{Minor hypothesis:}

1 - There is a relation between ownership concentration and unusual manufacturing expenses.

2- There is a relation between ownership concentration and unusual voluntaryexpenses.

3 - There is a relation between independence of Board of Directors' members and unusual production expense. 
4 - There is a relation between independence of board of directors' members and unusual voluntary expenses.

\section{4) Research method:}

Since this paper seeks to improve decision-making in firms relevant to our survey field through using available models, methods and theories according to research objectives, it's an applied study, inductive conclusion method was utilized to explained results derived by descriptive method from the randomly selected sample while results were generalized statistical population. Since the base of data analysis history refers to the firm's previous performance, its post - event in terms of research design.

(A) Statistical population:

The study statistical population consists of 96 stock firms having the same fiscal year, being active during studied period, without financial intermediary or enterprise, that wereselected randomly. These companies performance was examined during a six-year periodfrom 2006 up to 2012.

\section{(B) Analysis methods:}

The below statistical methods were used for analyzing and describing data:

1)Descriptive methods: on the way of describing statistical sample and research findings we used mean parameters to amputation, variance, standard deviation and ranking tables and pictorial graphs.

2) The default analysis methods: because of using multivariate linear regression, defaults of this method were examined. So to examine normalization of independent and dependent variables distribution, Kolmogorov - Smirnov test was used and $\mathrm{F}$ lamer test was used for selection between pooled data and panel data.Hussmann test statistic was used for determining sectional units fixed or random differences, White test for variances heterogeneity. To examine independent errors or medical relation between independent variable Durbin Watson test wasused for.

3) Analyzing the relations between variables: multivariate linear regression was used for analyzing the relation between variables. T statistic and F statistic were used for generalizing parameters to the studied population and also to determine model and direction of relation.

\section{C) Research model:}

In this study the model of main relation between earnings management and other variables is as follows:

$\mathrm{Y}=\mathrm{F}(\mathrm{X} 1, \mathrm{X} 2)$, in this equation $\mathrm{Y}$ stands for and earnings. Management index, $\mathrm{X} 1$ : ownership concentration, $\mathrm{X} 2$ : board members' independence. Two criteria were used for earnings real management in accordance with ZarowinandCohen (2010). Unusualvoluntaryexpense was estimated via equation (1) and the relation remainder must be considered as the unusual voluntary expenses (ABEXP).

\section{(1) DISEXPit/TAit-1 $=\alpha 0(1 /$ TAit-1 $)+\alpha 1($ Salesit/TAit- 1$)+\lambda$ it}

DISEXPit: is the voluntary expense of $\mathrm{i}$ company at the end of $\mathrm{t}$ fiscal year that equals official and sales expense.

$\Delta$ Salesit; sales changes of $i$ company at the end of $t-1$ year and TAit-1 stands for total assets of the last year. Furthermore, abnormal production expenses were estimated via relation (2), in such a way that the relation remainder is considered as the criterion of abnormal production expenses (ABEXPENSE).

PRODit/TAit-1=a0 (1/TAit-1) $+\alpha 1($ Salesit/TAit-1) $+\alpha 2(\Delta$ Salesit /TAit-1 $)+\alpha 3(\Delta$ Salesit-1/TAit-1) + dit

PRODit is the production expenseof $i$ company at the end of $t$ year that equals final expense of sold goods + changes of inventory.

\section{5) Research findings:}

This section dealt with describing and analyzing the mentioned findings. First we describe the variables making use of the statistical indices, then we examined the defaults used in multivariate linear regression and at last the relations between variables were analyzed.

\section{A) The findings description}

Findings were described based on operational data and are summarized in table1.

\section{Table 1: findings description}

\begin{tabular}{|c|c|c|c|c|c|c|}
\hline Variable & Symbol & Mean & Median & Minimum & Maximum & St. deviation \\
\hline $\begin{array}{c}\text { Earnings real management } \\
\text { based on production expenses }\end{array}$ & EMA1 & $-5 / 95$ & $-0 / 009$ & $-0 / 11$ & $0 / 25$ & $0 / 04$ \\
\hline $\begin{array}{c}\text { earnings real management } \\
\text { based on voluntary expenses }\end{array}$ & EMA2 & $3 / 12$ & $0 / 015$ & $-0 / 56$ & $0 / 68$ & $0 / 14$ \\
\hline
\end{tabular}




\begin{tabular}{|c|c|c|c|c|c|c|}
\hline Ownership concentration & OC & $0 / 76$ & $0 / 81$ & $0 / 09$ & $0 / 99$ & $0 / 2$ \\
\hline $\begin{array}{c}\text { Board of directors' } \\
\text { independence }\end{array}$ & IB & $0 / 58$ & $0 / 6$ & 0 & 1 & $0 / 25$ \\
\hline Firm size & SIZE & $13 / 1$ & $12 / 9$ & $9 / 78$ & $17 / 89$ & $1 / 22$ \\
\hline Profitability & ROA & $0 / 12$ & $0 / 1$ & $-0 / 33$ & $0 / 64$ & $0 / 12$ \\
\hline financial leverage & Lev & $0 / 65$ & $0 / 66$ & $0 / 07$ & $0 / 9$ & $0 / 17$ \\
\hline
\end{tabular}

Ownership concentration mean equals $76 \%$ in the studied companies the region the mentioned period. Ownership concentration median was also $81 \%$. Ownership concentration minimum and maximumwere respectively $9 \%$ and $99 \%$. This variable standard deviation alsois $20 \%$. Board of Directors' independence was $58 \%$. In other words $58 \%$ of board positions of the related companies belonged to board non-bound members. Mean and median symmetry of the variables and their standard deviation imply that the information is almost normal.

B) Defaults analysis: multivariate linear regression was used to determine the relations between dependent and independent variables, having some defaults, including variables distribution normality and . . . that had been examined.

1) Evaluating variables distribution normality: this evaluation is based on Kolmogorov - Smirnov test and primary results show that the significance level was lower than 1 and $5 \%$, and normalization of variables distribution is being rejected in $95 \%$ confidence. To remove this problem transformation of squares logarithm was used and again dis tribution normalization test was repeated. In case of transformational variables, results confirmed the normality of variables distribution.

2) Linear independence of independent variables: an outer default was to use multivariate linear regression, proving additiveassumption or independent variables linear independence from each other. Pearson correlation analysis was performed in order to evaluate this default. Table 2 shows the summary of results.

Table 2: evaluating linear independence of independent variables

\begin{tabular}{|l|l|l|l|l|l|l|l|} 
& EM1 & EM2 & SIZE & LEV & ROA & OC & IB \\
\hline EM1 & 1.000000 & -0.152072 & -0.086336 & 0.030207 & -0.098688 & -0.117769 & -0.072854 \\
\hline EM2 & -0.152072 & 1.000000 & 0.054115 & 0.221129 & -0.499211 & -0.002170 & -0.166944 \\
\hline SIZE & -0.086336 & 0.054115 & 1.000000 & -0.074537 & 0.117975 & 0.131448 & -0.088965 \\
\hline LEV & 0.030207 & 0.221129 & -0.074537 & 1.000000 & -0.464195 & 0.111905 & -0.131482 \\
\hline ROA & -0.098688 & -0.499211 & 0.117975 & -0.464195 & 1.000000 & 0.031892 & 0.160530 \\
\hline OC & -0.117769 & -0.002170 & 0.131448 & 0.111905 & 0.031892 & 1.000000 & -0.066360 \\
\hline IB & -0.072854 & -0.166944 & -0.088965 & -0.131482 & 0.160530 & -0.066360 & 1.000000 \\
\hline
\end{tabular}

According to table 2 results, since correlation coefficients between independent variables tends toward zero so the assumption of variables linear independence can be accepted.

3) Variances homogeneity: White test was used and results showed that since significance level is higher than $5 \%$ for both estimated relations sozero assumption was accepted on the basis of variance of similarity(homology) and a squares minimum method can be applied to estimate the relation between variables. Test results are shown in table 3 .

Table 3: White test results with $95 \%$ confidence level

\begin{tabular}{|cccc|}
$\begin{array}{c}\text { The } \\
\text { relation }\end{array}$ & F statistic & Significance level & Test results \\
\hline No 1 & 0.641 & 0.7163 & Variances are homogeneous \\
\hline No 2 & 0.63 & 0.7326 & Variances are homogeneous \\
\hline
\end{tabular}

4) Evaluating selection method to analyze panel data: $F$ Lamer test andHussmanntest were used. Both tests results indicated a significance level higher than $5 \%$ so collating method was used on the basis of fixed effects.

C) Analyzing the relation between variables: 
Regarding the proven defaults as explained before, here a multivariate linear regression is used for determining the relation between variables.

1) Earnings management on the basis of abnormal voluntary expenses: in this evaluation, earnings management was performed based on the first defined equation in the conducted research and abnormal voluntary expenses were computed as the model remainder then its relation with corporate governance determinants was estimated. The summary of these results is available in table 4. The research Main independent variables are corporate governance elements including (IB or OC) ownership concentration and board independence Along with other variables of firm size, financial leverage and efficiency up shareholders' salary. The below analysis would be derived by this table figures:

The first: the coefficient of ownership concentration independence variable as the first element, corporate governance equals 0.006 and and positive so there is a direct relation between corporate governance and earnings management based on voluntaryexpenses. Its significance level is greater than $5 \%$ in the last column; this relation can be considered significant in statistical population.

The second: independent variable coefficient of the board independence as the second component of corporate governance equals- 0.007 since it is negative so there's a reverse relation between corporate governance and earnings management based on voluntary expenses. Their significance level tending to zero is lower than $5 \%$ in the last column, so this relation can be considered significant in statistical population.

The thirst: coefficients of other size variables, financial leverage and shareholders salary efficiency were respectively $0.008,-0.014,-0.04$, and since it is negative so there's a reverse relation between earnings management and variables of firm size, financial leverage and shareholders salary efficiency. The significance level is higher than $5 \%$ in the last column and it can't be considered significantin statistical population.

Durbin Watson statistic was 1.36 in this table and it's between 1.5 up to 2.5; and the independent errors of estimated relation can be accepted. Furthermore, coefficient of estimated relation, tending to zero it equals 0.19 indicating that there's a weak linear relation between corporate governance elements and earnings management based on unusual voluntary expenses.

Table4: results derived from model process

\begin{tabular}{|c|c|c|c|c|}
\hline variable & coefficient & Standard deviation & T statistic & Significance level \\
\hline Constant & $0 / 119$ & $0 / 015$ & $7 / 869$ & $0 / 000$ \\
\hline OC & $0 / 006$ & $0 / 006$ & $1 / 003$ & $0 / 3160$ \\
\hline IB & $-0 / 007$ & $0 / 0019$ & $-3 / 89$ & $0 / 0001$ \\
\hline Size & $-0 / 008$ & $0 / 0009$ & $-8 / 112$ & $0 / 000$ \\
\hline Lev & $-0 / 014$ & $0 / 003$ & $-4 / 578$ & $0 / 000$ \\
\hline ROA & $-0 / 04$ & $0 / 0047$ & $-8 / 745$ & $0 / 000$ \\
\hline $\begin{array}{c}\text { Determination } \\
\text { coefficient }\end{array}$ & $0 / 19$ & Adjusted coefficient of determination & $0 / 052$ \\
\hline F statistic & $1 / 36$ & \multicolumn{2}{|c|}{ Durbin Watson } \\
\hline F possibility & $(0 / 0015)$ & \multicolumn{2}{|c|}{ Significance level } & $1 / 17$ \\
\hline
\end{tabular}

2) Earnings management on the basis of production abnormal expenses: in this survey, an earnings management was performed based on second equation defined in research model andabnormal productionexpenses were calculated as the model remainder then its relation to corporate governance elements was estimated. Results summary is shown in table 4. Research Main independent variables are corporate governance elements including (IB and OC) ownership concentration and board of directors' independence outlines the other variables of company size, financial leverage and shareholders salary efficiency. We can analyze as follow based on this table contents:

The first: coefficient of ownership concentration independent variable as the first element of corporate governance equals -0.12 , since it is negative so there is a reverse relation between corporate governance and earnings management on the basis of production expenses. Its significance level well under the last column equals $5 \%$.

Durbin Watson statistic was between 1.5 of 22.5 in table 6.1 and errors independence of the estimated relation can be accepted. Furthermore estimated relation coefficient of determination equals 0.49 being close to 0.5 Beth reveals a linear relation between corporate governance elements and earnings management on the basis of unusual production expense in the average extent.

Table 5: results obtained from model process 


\begin{tabular}{|c|c|c|c|c|}
\hline variable & coefficient & $\begin{array}{l}\text { Standard } \\
\text { deviation }\end{array}$ & T statistic & Significance level \\
\hline Constant & $-0 / 03$ & $0 / 034$ & $-0 / 85$ & 0/3915 \\
\hline OC & $-0 / 012$ & 0/015 & $-0 / 82$ & 0/4098 \\
\hline IB & $-0 / 044$ & $0 / 012$ & $-3 / 68$ & 0/0002 \\
\hline Size & 0/012 & 0/002 & $4 / 92$ & $0 / 000$ \\
\hline Lev & $-0 / 021$ & $0 / 021$ & $-1 / 01$ & $0 / 3125$ \\
\hline ROA & $-0 / 65$ & 0/031 & $-21 / 21$ & $0 / 000$ \\
\hline $\begin{array}{l}\text { Determination } \\
\text { coefficient }\end{array}$ & $0 / 49$ & \multicolumn{2}{|c|}{ Adjusted coefficient of determination } & $0 / 48$ \\
\hline F statistic & 127 & \multicolumn{2}{|c|}{ Durbin Watson } & $1 / 6$ \\
\hline F possibility & $(0 / 000)$ & \multirow{3}{*}{\multicolumn{2}{|c|}{ Hussman test of Significance level }} & \\
\hline chaw's significance & $3 / 1$ & & & $58 / 5$ \\
\hline test & $(0 / 000)$ & & & $(0 / 000)$ \\
\hline
\end{tabular}

\section{6) Conclusion:}

According to the empirical bases it was expected that there will be a relation between corporate governance elements including board independence, ownership concentration and earnings real management. So a statistical sample was selected by simple random sampling method consisting of 96 companies amongst accepted companies in Tehran stock exchange. The studied time span was from 2006 up to 2012. Regarding the applied trend in some similar researches, we made use of multivariate linear regression with analyzing combined data to determine the relation between variables. While the relevant defaults to the use of this method was examined beforehand. Examinations results showed that:

1. There's a significant and reverse relation between corporate governance and earnings real management on the basis of board independence. In other words, companies with a higher percentage of board non-bound members would have less incentives for earnings real management.

2. According to research findings there seems not to be any significant relation between ownership concentration and earnings real management on the basis of unusual production expenses.

3. Regarding research findings there seems not to be any significant relation between ownership concentration and earnings real management on the basis of unusual voluntary expenses.

4. Regarding research findings there is a reverse and significant relation between board independence and earnings real management on the basis of production unusual expenses.

5. Regarding research findings there is a negative and significant relation between board independence and real earnings management on the basis of unusual voluntary expenses.

6. There seems to be a reverse and significant relation between profitability, financial leverage and company size and real earnings management on the basis of unusual production expenses.

7. There was a significant and reverse relation between profitability and real earnings management but a direct and significant relation between company size and real earnings management on the basis of voluntary production expenses.

\section{References:}

1. Agrawal, A., \&Knoeber, C. R. (1996). Firm performance and mechanisms to control agency problems between managers and shareholders.Journal of financial and quantitative analysis, 31(03), 377-397.

2. Anderson, K. L., Gillan, S., \& Deli, D. N. (2003). Boards of directors, audit committees, and the information content of earnings. Weinberg Center for Corporate Governance Working Paper, (2003-04).

3. Almazan, A., Hartzell, J. C., \& Starks, L. T. (2005). Active institutional shareholders and expenses of monitoring: Evidence from executive compensation. Financial Management, 34(4), 5-34.

4. Black, B. S. (1998). Shareholder activism and corporate governance in the United States. As published in The New Palgrave Dictionary of Economics and the Law, 3, 459-465.

5. Beasley, M. S. (1996). An empirical analysis of the relation between the board of director composition and financial statement fraud. Accounting Review, 443-465. 
6. Burgstahler, D., \&Dichev, I. (1997). Earnings management to avoid earnings decreases and losses. Journal of accounting and economics, 24(1), 99-126.

7. Bushee, B. J. (1998). The influence of institutional investors on myopic R\&D investment behavior. Accounting review, 305-333.

8. Bennedsen, M., \&Wolfenzon, D. (2000). The balance of power in closely held corporations. Journal of financial economics, 58(1), 113-139.

9. Black, B. (2001). The corporate governance behavior and market value of Russian firms. Emerging Markets Review, 2(2), 89-108.Balsam, S., Bartov, E., \& Marquardt, C. (2002). Accruals management, investor sophistication, and equity valuation: Evidence from 10-Q filings. Journal of Accounting Research, 40(4), 9871012.

10. Bhattacharya, P. S., \& Graham, M. (2007). Institutional ownership and firm performance: evidence from Finland. School of Accounting, Economics and Finance.

11. Ben Ali, C. (2009). Disclosure quality and corporate governance in a context of minority expropriation. Available at SSRN 1406149.

12. Bergstresser, D., \&Philippon, T. (2006). CEO incentives and earnings management. Journal of Financial Economics, 80(3), 511-529.

13. Chtourou, S. M., Bedard, J., \&Courteau, L. (2001). Corporate governance and earnings management. University of Laval, Quebec, Canada.

14. Chung, R., Firth, M., \& Kim, J. B. (2002). Institutional monitoring and opportunistic earnings management. Journal of Corporate Finance, 8(1), 29-48.

15. Cheng, E. and Courtenay, S.(2006). Board composition, regulatory regime and voluntary disclosure. International Journal of Accounting, Vol. 41, pp. 262-89.

16. Cohen, D. A., \&Zarowin, P. (2010). Accrual-based and real earnings management activities around seasoned equity offerings. Journal of Accounting and Economics, 50(1), 2-19.

17. Chang, J. C. (2008). Earnings Informativeness, Earnings Management and Corporate Governance Under the Sarbanes-Oxley Act of 2002. ProQuest.

18. Chang, J. C., \& Sun, H. L. (2008). The relation between earning informativeness, earnings management and corporate governance in the pre-and post-SOX periods.working paper, Morgan State University.

19. Chung, K. H., \& Zhang, H. (2011). Corporate governance and institutional ownership.Journal of Financial and Quantitative Analysis, 46(01), 247-273.

20. Chung, K. H., Elder, J., \& Kim, J. C. (2010). Corporate governance and liquidity.

21. Chang, J. C., \& Sun, H. L. (2009). Crossed-listed foreign firms' earnings informativeness, earnings management and disclosures of corporate governance information under SOX. The International Journal of Accounting, 44(1), 1-32.

22. Chang, J. C., \& Sun, H. L. (2010). Does the disclosure of corporate governance structures affect firms' earnings quality?.Review of Accounting and Finance, 9(3), 212-243.

23. Chtourou, S. M., Bedard, J., \&Courteau, L. (2001). Corporate governance and earnings management. University of Laval, Quebec, Canada.

24. Demsetz, H., \& Lehn, K. (1985). The structure of corporate ownership: Causes and consequences. The Journal of Political Economy, 1155-1177.

25. Dempsey, S. J., Hunt, H. G., \& Schroeder, N. W. (1993). Earnings management and corporate ownership structure: An examination of extraordinary item reporting. Journal of Business Finance \& Accounting, 20(4), 479500 .

26. Dechow, P. M., \& Skinner, D. J. (2000). Earnings management: Reconciling the views of accounting academics, practitioners, and regulators. Accounting Horizons, 14(2), 235-250.

27. Dechow, P. M., Sloan, R. G., \& Sweeney, A. P. (1996). Causes and consequences of earnings manipulation: An analysis of firms subject to enforcement actions by the sec*. Contemporary accounting research, 13(1), 1-36.

28. Darrough, M. N., Pourjalali, H., \&Saudagaran, S. (1998). Earnings management in Japanese companies. The International Journal of Accounting, 33(3), 313-334.

29. Degeorge, F., Patel, J., \&Zeckhauser, R. (1999). Earnings Management to Exceed Thresholds*. The Journal of Business, 72(1), 1-33.

30. Davidson III, W. N., Xie, B., Xu, W., \&Ning, Y. (2007). The influence of executive age, career horizon and incentives on pre-turnover earnings management. Journal of Management \& Governance, 11(1), 45-60.

31. Epps, R. W., \& Ismail, T. H. (2009). Board of directors' governance challenges and earnings management. Journal of Accounting \& Organizational Change, 5(3), 390-416.

32. Fosberg, R. H. (1989). Outside directors and managerial monitoring.Akron Business and Economic Review, 20(2), 24.

33. Frank Yu, F. (2006).Corporate governance and earnings management.Carlson School of Management, University of Minnesota, Minneapolis.

34. Firth, M., Fung, P. M., \&Rui, O. M. (2007). Ownership, two-tier board structure, and the informativeness of earnings-Evidence from China.Journal of accounting and public policy, 26(4), 463-496.

35. Gul, F. A., \& Leung, S. (2004). Board leadership, outside directors' expertise and voluntary corporate disclosures.Journal of Accounting and public Policy, 23(5), 351-379.

36. Gunny, K. A. (2005). What are the consequences of real earnings management?

37. Gunny, K. A. (2010). The Relation Between Earnings Management Using Real Activities Manipulation and Future Performance: Evidence from Meeting Earnings Benchmarks*. Contemporary Accounting Research, 27(3), 855888. 
38. Hermalin, B. E., \&Weisbach, M. S. (1991). The effects of board composition and direct incentives on firm performance. Financial management, 101-112.

39. Healy, P. M., \&Wahlen, J. M. (1999). A review of the earnings management literature and its implications for standard setting. Accounting horizons, 13(4), 365-383.

40. Himmelberg, C. P., Hubbard, R. G., \&Palia, D. (1999). Understanding the determinants of managerial ownership and the link between ownership and performance. Journal of financial economics, 53(3), 353-384.

41. Hashim, H. A., \& Devi, S. S. (2007). Corporate governance, ownership structure and earnings quality: Malaysian evidence. Research in Accounting and Emerging Economies, 8, 97-123.

42. Imam, M. O., \& Malik, M. (2007). Firm performance and corporate governance through ownership structure: Evidence from Bangladesh stock market. International Review of Business Research Papers, 3(4), 88-110.

43. Jensen, M. C. (1986). Agency expenses of free cash flow, corporate finance, and takeovers. The American economic review, 323-329.

44. Jensen, M. C. (1993). The modern industrial revolution, exit, and the failure of internal control systems.the Journal of Finance, 48(3), 831-880.

45. Jiambalvo, J., Rajgopal, S., \&Venkatachalam, M. (2002). Institutional Ownership and the Extent to which Stock Prices Reflect Future Earnings*.Contemporary Accounting Research, 19(1), 117-145.

46. Jae-Seung B., Jun-koo K. and Kyung-Suh P. (2004). Corporate governance and firm value: evidence from Korean financial crisis, Journal of Financial Economics, Vol.71,: p.265-313.

47. Jiang, W., Lee, P., \&Anandarajan, A. (2008). The association between corporate governance and earnings quality: further evidence using the GOV-Score. Advances in Accounting, 24(2), 191-201.

48. Klein, A. (2002). Audit committee, board of director characteristics, and earnings management. Journal of accounting and economics, 33(3), 375-400.

49. Koh, P. S. (2003). On the association between institutional ownership and aggressive corporate earnings management in Australia. The British Accounting Review, 35(2), 105-128.

50. Kouki, M., Elkhaldi, A., Atri, H., \&Souid, S. (2011). Does corporate governance constrain earnings management? Evidence from US firms. European Journal of Economics, Finance and Administrative Sciences, 35, 58-71.

51. Kapopoulos, P., \&Lazaretou, S. (2007). Corporate ownership structure and firm performance: evidence from Greek firms. Corporate Governance: An International Review, 15(2), 144-158.

52. Kinney Jr, W. R., \& Libby, R. (2002). Discussion of the relation between auditors' fees for nonaudit services and earnings management. The Accounting Review, 77(s-1), 107-114.

53. Lehmann, E., \&Weigand, J. (2000). Does the governed corporation perform better? Governance structures and corporate performance in Germany. European Finance Review, 4(2), 157-195.

54. LAWLER III, E. E., Finegold, D. L., Benson, G. S., \& Conger, J. A. (2002). Corporate boards: keys to effectiveness. Organizational Dynamics, 30(4), 310-324.

55. Morck, R., Shleifer, A., \&Vishny, R. W. (1988). Management ownership and market valuation: An empirical analysis. Journal of financial Economics, 20, 293-315.

56. MarrakchiChtourou, S., Bédard, J., \&Courteau, L. (2001).Corporate Governance and Earnings Management. Corporate Governance and Earnings Management (April 21, 2001).

57. Mueller, E., \& Spitz-Oener, A. (2006). Managerial ownership and company performance in German small and medium-sized private enterprises. German Economic Review, 7(2), 233-247.

58. Niu, F. F. (2006). Corporate governance and the quality of accounting earnings: a Canadian perspective. International Journal of Managerial Finance, 2(4), 302-327.

59. Nelson, J. (2011). Corporate governance mechanisms and earnings management in transitional countriesEvidence from Chinese listed firms (Doctoral dissertation, Queensland University of Technology).

60. Osma, B. G., \&Noguer, B. G. D. A. (2007). The effect of the board composition and its monitoring committees on earnings management: Evidence from Spain. Corporate Governance: An International Review, 15(6), 1413-1428.

61. Peasnell, K. V., Pope, P. F., \& Young, S. (2005). Board monitoring and earnings management: do outside directors influence abnormal accruals?.Journal of Business Finance \& Accounting, 32(7-8), 1311-1346.

62. Pope, P., Peasnell, K., \& Young, S. (1998). Outside directors, board effectiveness, and earnings management.

63. Peasnell, K. V., Pope, P. F., \& Young, S. (2000). Detecting earnings management using cross-sectional abnormal accruals models. Accounting and Business research, 30(4), 313-326.

64. Peasnell, K. V., Pope, P. F., \& Young, S. (2005). Board monitoring and earnings management: do outside directors influence abnormal accruals?. Journal of Business Finance \& Accounting, 32(7-8), 1311-1346.

65. Peng, L. H. W. R. (2010). The Effects of Corporate Governance on Earnings Quality: Evidence from Chinese Listed Companies. Journal of Shandong University (Philosophy and Social Sciences), 1, 006.

66. Rosenstein, S., \& Wyatt, J. G. (1990). Outside directors, board independence, and shareholder wealth. Journal of financial economics, 26(2), 175-191.

67. Ramsay, I. M., \& Blair, M. (1993). Ownership concentration, institutional investment and corporate governance: an empirical investigation of 100 Australian companies. Melb. UL Rev., 19, 153.

68. Rechner, P. L., \& Dalton, D. R. (1991). CEO duality and organizational performance: A longitudinal analysis. Strategic Management Journal, 12(2), 155-160.

69. Rajgopal, S., Venkatachalam, M., \&Jiambalvo, J. J. (1999). Is institutional ownership associated with earnings management and the extent to which stock prices reflect future earnings?. Available at SSRN 163433.

70. Ramsey, A., Oei, R., \& Mather, P. (2005). Earnings quality and its relationship with Aspects of Corporate Governance: an Investor Perspective. Accounting and Financial Association of Australia and new Zeeland.

71. Roychowdhury, S. (2006).Earnings management through real activities manipulation. Journal of accounting and economics, 42(3), 335-370. 
72. Rahman, R. A., \& Ali, F. H. M. (2006). Board, audit committee, culture and earnings management: Malaysian evidence. Managerial Auditing Journal, 21(7), 783-804.

73. Rosenberg, M. (2003). Corporate governance mechanisms and firm performance: evidence from Finland. Swedish School of Economics and Business Administration.

74. Setia-Atmaja, L., Haman, J., \&Tanewski, G. (2011). The role of board independence in mitigating agency problem II in Australian family firms. The British Accounting Review, 43(3), 230-246.

75. Shah, S. Z. A., Zafar, N., \&Durrani, T. K. (2009). Board Composition and Earnings Management an Empirical Evidence Form Pakistani Listed Companies. Middle Eastern Finance and Economics, 3(29), 30-44.

76. Sivaramakrishnan, S., \& Yu, S. C. (2008). On the association between corporate governance and earnings quality.Retrieved July, 7, 2009.

77. Siregar, S. V., \&Utama, S. (2008). Type of earnings management and the effect of ownership structure, firm size, and corporate-governance practices: Evidence from Indonesia. The International Journal of Accounting, 43(1), 1 27.

78. Saleh, N. M., Iskandar, T. M., \&Rahmat, M. M. (2005). Earnings management and board characteristics:

79. Velury, U., \& Jenkins, D. S. (2006). Institutional ownership and the quality of earnings. Journal of Business Research, 59(9), 1043-1051.

80. Xie, B., Davidson III, W. N., \&DaDalt, P. J. (2003). Earnings management and corporate governance: the role of the board and the audit committee. Journal of corporate finance, 9(3), 295-316.

81. Yermack, D. (1996). Higher market valuation of companies with a small board of directors. Journal of financial economics, 40(2), 185-211.

82. Yu, F. (2006). Corporate governance and earnings management. Carlson School of Management, University of Minnesota, Minneapolis.

83. Yu, W. (2008). Accounting-based earnings management and real activities manipulation.ProQuest.

84. Zouari, A., \&Rebaï, I. (2009). Institutional ownership differences and earnings management: A neural networks approach. International Research Journal of Finance and Economics, 34, 42-55.

85. Domestic References:

86. Ahmad Poor, Ahmad. (2010). Evaluating the non-bound managers' role in investors' on earnings management manner based on the threshold model. Accounting researches, 16(58): 1- 20.

87. Aghaie, Mohammad Ali and PariChalaki (2010). Evaluating the relation between corporate governance characteristics and earnings management in the firms of Tehran stock exchange. Accounting researches, first year, number four, PP $54-77$.

88. Ashrafi, Mehdi (2011). Evaluating the relation of the firm strategic system mechanisms with Invesco position in the accepted companies by Tehran stock exchange. Master thesis, Islamic Azad University, Mobarakeh branch.

89. Asta,Sohrab (2012). Evaluating the relation between and earnings management and invest composition within accepted companies in Tehran stock exchange market. Journal of financial accounting researches number two, PP 93- 109

90. EbrahimiKordlar, Ali and Mohammad JavadAraabi.(2011). Journal of financial accounting researches, $2^{\text {nd }} y e a r$, number two, serial number 4, pp95-110

91. Fazlzade,Alireza; Mohammadzade, Parviz and Ali TahbazHendi.(2010). Evaluating ownership composition effects on firms performance of the accepted firms in Tehran stock exchange market sortedby industry.quarterly of stock exchange market, fall 88, number 7, PP 5 - 33.

92. Hadavi, E (2009). Evaluating the relation between earnings quality and some aspects of corporate governance in the accepted companies by Tehran stock exchange market.master thesis, Islamic Azad University,Borujerd branch.

93. Izadinia, Naser and Amir Rasaian (2011). The relation of some corporative strategic monitoring devices and financial and economic criteria for operation assessment. Journal of accounting science, number one, PP $53-73$.

94. Ismail ZadeMafari, Ali, Mohammad Jalili and Abbas Zand Abbas Abaadi I. (2011). Evaluating corporate governance effects on and earnings quality in Tehran exchange market. Journal of management accounting, 3rd year, number seven, PP $51-63$

95. Khoshtinat, Mohsen and KhaniAbdollah (2004). Earnings management and managers rewards: a study to clarify financial information. Clark Terry L accounting studies, number three PP 127 - 153

96. Karimi, Farzad,Ashrafi, Mehdi (2012).Evaluating mechanisms relation of firm strategic system and invest composition in Tehran stock exchange market. Financial accounting researches 2, PP $79-92$.

97. Mahdavi, Abolghasem, Midri, Ahmad (2006). Ownership composition and efficiency of active firms in Tehran stock exchange market.Journal of economic surveys, No71, PP $103-132$

98. Mazloomi, Nader (2004).The relation between institutional investors' managerial performance and ownership portion in institutions and accepted companies in Tehran stock exchange market.PhD thesis by Dr. Hossain Rahmanseresht's guide, departmental management and accounting of Tehran AllamehTabatabaie University.

99. Mashayekhi, Bita, Safari, Maryam (2007). The cash resulted from earnings management and operation throughout companies accepted in Tehran stock exchange market. Auditing and accounting evaluations, 44, PP $35-54$.

100. Mahavar Poor, Razieh (2008) evaluating ownership concentration is based on the performance of the accepted companies by Tehran stock exchange market, master thesis, Alzahra University.

101.Moradzadefard, Mehdi; NazemiArdekani, Mehdi; GholamiJamcarani, Reza and HojjatollahFarzani.(2010). Evaluating the relation between shares institutional ownership and earnings management in the accepted companies by Tehran stock exchange market.Auditing and accounting evaluations, number 55, PP 85 - 98. 
102. Mashayekhi, Bita, MehdiMohamamdabadi. (2012). the relation of corporate governance mechanisms with Earnings quality. Financial accounting researches 2, PP $17-32$.

103. Noravesh, Iraj and AliEbrahimiKordlar. (2006). Evaluating and describing the combination relation of shareholders with information symmetry and performance accounting criteria proficiency. Auditing and accounting evaluations, number 42, PP $97-124$.

104.Namazi, Mohammad and Kermani, Ehsan. (2008). ownership composition effects on company performance being accepted in Tehran stock exchange market petition board. Auditing and accounting evaluations, 53.

105.Namazi, Mohammad and Kermani, Ehsan. (2009).Ownership composition effect on the performance of accepted companies by Tehran stock exchange market. Quarterly of auditing and accounting evaluations, number 53.

106. Nasrollahi, Zahra and ZohrehArefmanesh. (2011). Evaluating ownership relation with earnings quality in the accepted companies by Tehran stock exchange. Journal of accounting, first year, number three, PP 117- 138.

107.Nikbakht, Mohammad Reza andJavadRahmaniNia. (2011). evaluating institutional ownership effects on performance of the accepted firm in Tehran stock exchange market. Quarterly of stock exchange market, spring 89, number nine PP $43-60$.

108. RahnamayRudposhti, Fereidun et al. (2006).Offering paradigm to measure corporate governance mechanisms effects on earnings management in Tehran stock exchange market. Exploratory and scientific quarterly of management accounting, $5^{\text {th }}$ year, number 12, spring 91

109.Setayesh, Mohammad Hossein, Ghorbani, Asghar and Golmohammadi, Maryam. (2011).Evaluating corporate governance effects on air earnings flattening of the companies accepted by Tehran stock exchange market.Accounting researches, number seven, PP $34-51$.

110.Vakilifard, Hamidreza and LidaBavandpoor. (2011).Corporate governance effects on the performance of accepted firms by Tehran stock exchange market. Journal of financial studies, number 8, PP $119-133$

111.Vali Poor, Hashem and Ali Khoram. (2012). Effectiveness of company strategic system mechanisms in order to degrees agency expenses. Journal of management accounting, no. 8, PP $61-75$

112. Yazdanian, Narges (2007). The role of corporate governance in and earnings management reduction. $A$ thesis for getting master degree in TehranAllamehTabatabaie University.

113. Yazdanian, Narges. (2008). Corporate governance effects on earnings management. Masterthesis, AllamehTabatabaie University.

114.-Zanjirdar,Majid; Amirhosseini, Zahra and MajidZamanai. (2011).Evaluating the relation between firms strategic mechanisms and earnings management in Iran in this market. Journal of management and financial engineering, No3. 